\title{
PENGARUH IMPLEMENTASI MEDIA PEMBELAJARAN BERBASIS E-LEARNING SCHOOLOGY PADA MATA PELAJARAN DASAR LISTRIK DAN ELEKTRONIKA DI SMK MITRA INDUSTRI MM2100 KELAS X JURUSAN TEKNIK ELEKTRONIKA INDUSTRI
}

\author{
Muhammad Najib Ridwan ${ }^{1}$, Moch Sukardjo², Wisnu Djatmiko \\ ${ }^{1}$ Mahasiswa Prodi Pendidikan Teknik Elektronika, Fakultas Teknik - UNJ \\ ${ }^{2}$ Dosen Prodi Pendidikan Teknik Elektronika, Fakultas Teknik - UNJ \\ ${ }^{3}$ Dosen Prodi Pendidikan Teknik Elektronika, Fakultas Teknik - UNJ
}

\begin{abstract}
Abstrak Penelitian ini bertujuan untuk mengetauhi pengaruh implementasi media pembelajaran berbasis e-learning schoology pada mata pelajaran dasar listrik dan elektronika di smk mitra industri mm2100 kelas x jurusan teknik elektronika industri. Penelitian ini menggunakan metode Eksperimen yaitu menggunakan metode Preexperimental Design dengan desain penelitian "One Group Pretest-Postest Design". Populasi dalam penelitian ini adalah peserta didik kelas X Jurusan Teknik Elektronika Industri SMK Mitra Industri MM 2100 Tahun Ajaran 2018/2019. Teknik Pengambilan sample menggunakan Teknik Probability Sampling dengan teknik Simple Random Sampling, sampel yang digunakan adalah peserta didik kelas X Elind 1 Teknik Elektronika Industri MM 2100 sebagai kelas eksperimen yang belajar menggunakan media pembelajaran berbasis ELearning Schoology pada mata pelajaran dasar listrik dan elektronika. Instrumen Penelitian berupa tes pilihan ganda sebanyak 72 butir soal. Uji persyaratan analisis dilakukan melalui uji normalitas. Pengujian normalitas dengan menggunakan uji Chi Kuadrat pada pretest, diperoleh yaitu 4,880 < 11,070 sehingga data berdistribusi normal, sedangkan pada posttest diperoleh yaitu $7,756<11,070$ sehingga data berdistribusi normal untuk kedua pretest dan postest. Pengujian hipotesis menggunakan rumus uji-t untuk dua sample related yang diperoleh thitung $>$ ttabel yaitu 38,60 >1,68 pada taraf signifikansi $=0,05$, maka Ho ditolak dan Ha diterimasehingga dapat disimpulkan bahwa terdapat pengaruh positif terhadap hasil belajar peserta didik dengan menggunakan media pembelajaran berbasis elearning schoology pada mata pelajaran dasar listrik dan elektronika di smk mitra industri mm2100 kelas X Elind 1 jurusan teknik elektronika industri di SMK Mitra Industri MM 2100.
\end{abstract}


Kata Kunci: Media pembelajaran, e-learning, schoology, Hasil belajar peserta didik, DasarListrik dan Elektronika

\section{Pendahuluan}

Belajar adalah suatu proses yang kompleks yang terjadi pada diri setiap orang sepanjang hidupnya. Proses belajar itu terjadi karena adanya interaksi antara sesorang dengan lingkunganya. Oleh karena itu, belajar dapat terjadi kapan saja dan dimana saja. Salah pertanda bahwa sesorang itu telah belajar adalah adanya perubahan pada tingkat pengetahuan, keterampilan, atau sikapnya (Arsyad, Azhar, 2011:1). Pada hasil pengamatan jam pelajaran Dasar Listrik dan Elektronika pada saat proses tatap muka dikelas terlihat peserta didik hanya memperhatikan guru yang sedang menjelaskan materi yang sedang diajarkan. sehingga terlihat proses pembelajaran hanya terjadi satu arah saja padahal di SMK Mitra Industri MM2100 terdapatnya fasilitas jaringan internet yang kurang dimanfaatkan secara optimal untuk pembelajaran. Selain itu masalah yang dihadapkan oleh peserta didik kelas X Elind 1 dalam proses pembelajaran adalah dikarenakan guru mata pelajaran khususnya mata pelajaran dasar listrik dan elektronika jarang hadir dikelas karena terdapat kesibukan diluar jam mengajar, sehingga anak anak kelas X Elind 1 sering didapati kelas kosong dan tidak mendapatkan materi atau pembelajaran. Hal tersebut terbukti dari nilai teori peserta didik kelas X Elind masih banyak peserta didik yang mendapatkan nilai dibawah kriteia kelulusan minimal (KKM) dan jumlahnya sangat banyak dibandingkan dengan peserta didik yang mendapatkan nilai diatas KKM, terlihat pada tabel 1.1 berikut ini.

TABEL 1.1 NILAI ULANGAN SISWA PADA MATA PELAJARAN DLE

\begin{tabular}{|c|c|c|c|c|c|c|c|}
\hline Kelas & KKM & $\begin{array}{c}\text { Jumlah } \\
\text { Siswa }\end{array}$ & $\begin{array}{c}\text { Jumlah } \\
\text { Peserta } \\
\text { didik } \\
\text { Tuntas }\end{array}$ & $\begin{array}{c}\text { Jumlah } \\
\text { Peserta } \\
\text { Didik } \\
\text { Tidak } \\
\text { Tuntas }\end{array}$ & $\begin{array}{c}\text { Nilai } \\
\text { Tertinggi }\end{array}$ & $\begin{array}{c}\text { Nilai } \\
\text { Terendah }\end{array}$ & Rata-Rata \\
\hline X ELIND 1 & $\geq 76$ & 40 & 9 & 31 & 100 & 30 & 65 \\
\hline
\end{tabular}

Pada Hasil pengamatan dan wawancara peneliti di SMK Mitra Industri MM 2100 menemukan pembelajaran yang digunakan dalam mata pelajaran Dasar Listrik dan Elektronika terdapat 3 aspek penilian yaitu aspek sikap, kognitif, dan praktik/keterampilan. Pada tiap aspek memiliki persentase peniliaian yang berbeda beda untuk sikap persentase nilai sebesar $50 \%$ aspek kognitif $17 \%$ dan yang terakhir yaitu aspek praktik/keterampilan sebesar 33\%. Rasio persentase nilai telah disesuaikan oleh tingkat kebutuhan industry Untuk mengatasi permasalahan yang telah diuraikan diatas salah satunya adalah dengan memanfaatkan sarana dan prasana yang telah disediakan di sekolah yaitu internet dan komputer, dalam hal ini maka perlu memanfaatkan media pembelajaran yang sesuai dan dapat digunakan dengan sarana yang sudah disiapkan oleh sekolah untuk menunjang kegiatas belajar peserta didik dalam penguasan teori. Media pembelajaran bisa menjadi alternatif dalam proses belajar dan mengajar untuk meningkatkan minat belajar peserta didik sehingga membuat para peserta didik semakin bersemangat dalam mengikuti proses belajar. pada era modern sumber pendidikan pun bisa didapat tidak hanya di sekolah, namun internet sudah banyak menyediakan materi pembelajaran yang biasa dikenal dengan istilah E-Learning. Pada media pembelajaran berbasis E-Learning terdapat banyak sekali seperti Schoology, Zenius, Edmodo, 
Quipper, dan Ruang guru. Sedangkan media yang diajukan oleh peneliti untuk menyelesaikan masalah yang telah diuraikan diatas adalah media Schoology. Schoology adalah jejaring sosial berbasis web khusus untuk K-12 (sekolah dan lembaga pendidikan tinggi) yang difokuskan pada kerjasama, untuk memungkinkan pengguna membuat, mengelola, dan saling berinteraksi serta berbagi konten akademis. Schoology juga memberikan akses pada guru dan peserta didik untuk presensi, pengumpulan tugas, latihan soal dan media sumber belajar yang bisa diakses kapanpun dan dimanapun serta juga memberikan akses pada orang tua untuk memantau perkembangan belajar peserta didik di sekolah. (Farmington, Schoology 2014). Dengan demikian media schoology dapat disimpulkan bahwa merupakan sebuah layanan pembelajaran berbasi online learning yang dapat diakses secara gratis oleh peserta didik maupun guru sebagai instruktur ataupun fasilitator dengan tampilan layaknya sosial media yang di khususkan untuk lingkungan pembelajaran berbasis online / e-learning Di dalam media schoology terdapat fitur fitur yang dapat menunjang terjadinya proses pembelajaran dalam dunia virtual yaitu seperti course yang berfungsi sebagai tempat guru ataupun fasilitator membuat sebuah mata pelajaran tertentu untuk diikuti oleh para peserta didik, kemudian terdapat fitur groups yang berfungsi sebagai fasilitas untuk membuat sebuah kelompok dan yang terakhir adalah fitur recourses yaitu sebuah fitur yang berfungsi sebagai sumber guru untuk menyimpan sebuah materi maupun ujian ataupun quiz. Dari uraian di atas, maka peneliti tertarik untuk mencoba melakukan penelitian dengan judul Pengaruh Implementasi Media Pembelajaran Berbasis E-Learning Schoology Pada Mata Pelajaran Dasar Listrik Dan Elektronika Di SMK Mitra Industri MM 2100 Kelas X Jurusan Teknik Elektronika Industri

\section{Metode}

\section{1 tempat dan waktu penelitian}

Penelitian Dilakukan Di SMK Mitra Industri MM2100 Yang Beralamat Di Jl. Kalimantan Blok DD 1-1 Kawasan Industri MM2100, Cikarang Barat, Kabupaten Bekasi.Waktu penelitian dilaksanakan di semester ganjil tahun ajaran 2018/2019 yaitu pada bulan November - Desember 2018

TABEL 2.1 JADWAL PELAKSANAAN PENELITIAN

\begin{tabular}{|c|c|c|}
\hline $\mathrm{N}_{0}$. & Waktu & Kepatan \\
\hline 1 & 20 Novembet 2017 & Surve tempatpentlain \\
\hline 2 & 24 Noventber 2017 & Penzinan penelitian ke phak sekotah \\
\hline 3 & 31 Aquastur 2018 & Pengujan valditas dan reha belas arnstrumen \\
\hline 4 & 30 Oktobet 2018 & Pelakuanaspotes dikelas Ekspetimea (X Elind I) \\
\hline 3 & $\begin{array}{l}2,3,5,9,10,12,13,19,23, \\
24,26 \text { Novembes } 10,18 \\
\text { Detiember } 2018\end{array}$ & $\begin{array}{l}\text { Kepatan Pembelajaran E-Leaming Kelas Ekspermen } \\
\text { (X Elind 1) }\end{array}$ \\
\hline 6 & 21 Devember 201 & Pelaksana anposttest dikelas Ekspenmen (X Elind I) \\
\hline 7 & 3 hasuan 2019 & 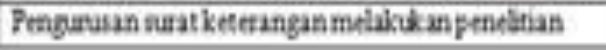 \\
\hline
\end{tabular}

\subsection{Populasi dan Sampel Penelitian}

Populasi dalam penelitian ini adalah peserta didik kelas X Elektronika Industri di SMK Mitra Industri MM2100 pada semester ganjil tahun ajaran 2018/2019. Teknik sampling 
yang digunakan dalam penelitian adalah Probability sampling dengan teknik Simple Random Sampling. maka terplilih yaitu kelas X Elind 1

\subsection{Metode dan Rancangan Penelitian}

Desain penelitian yang digunakan adalah Pre experimental design dengan bentuk One Group Pretest - Posttest Design yaitu suatu rancangan penelitian yang menggunakan 1 kelompok subjek untuk mengukur perubahan yang diakibatkan oleh suatu perlakuan. seperti ditunjukkan pada gambar berikut :

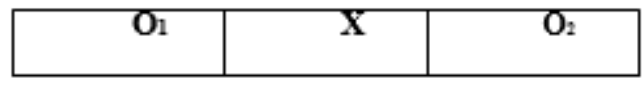

Gambar 2.1 Desain Penelitian Pre Experimental Design

Keterangan:

$\mathrm{O} 1=$ Nilai Pretest (sebelum diberi Perlakuan )

$\mathrm{O} 2=$ Nilai Posttest (Sesudah diberi perlakuan)

$\mathrm{X}=$ Perlakuan kelompok eksperimen dengan menggunakan media pembelajaran berbasis elearning schoology

\subsection{Perlakuan Penelitian}

Pada Awal penelitian akan diberikan pretest untuk mengukur kemampuan awal peserta didik. Kemudian peserta didik akan diberikan Proses pembelajaran berbasis E-Learning dengan menggunakan media pembelajaran berbasis E-Learning Schoology. Sementara di akhir penelitian akan diberikan posttest dengan instrumen berupa soal yang akan mengukur tingkat penguasaan dan hasil belajar peserta didik

\section{Hasil}

\subsection{Deskripsi Data}

\subsubsection{Validitas}

Hasil data perhitungan dari uji validitas dengan jumlah responden sebanyak 35 peserta didik dan sample berasal dari sekolah SMK MITRA INDUSTRI PUTRA DHARMA TAMBUN Kelas X Elind 1 adalah dari soal yang berjumalh 120 setelah dilakukan perhitungan dengan menggunakan rumus point biserial mendapatkan 72 soal yang valid dan 48 soal yang tidak valid

\subsubsection{Reabilitas}

Uji Reabilitas adalah uji untuk mengukur keajegan suatu soal. Rumus yang digunakan dalam penelitian ini menggunakan rumus K-R 20 dengan hasil sebesar 0,8632.

\subsubsection{Data Pretest dan Postest}

data data pretest dan postest ditunjukkan pada tabel 3.1 sebagai berikut : 
TABEL 3.1 DESKRIPSI DATA PENELITIAN

\begin{tabular}{|c|c|c|c|}
\hline \multirow[t]{2}{*}{ No, } & \multirow[t]{2}{*}{ Desknipsi } & \multicolumn{2}{|c|}{ Kelas Eksperimen } \\
\hline & & Pre-Test & Post-Test \\
\hline 1. & Nilai Terendah & 21 & 56 \\
\hline 2. & Nulai Tertinggi & 50 & 85 \\
\hline 3. & Mean & 35,65 & 75,97 \\
\hline 4. & Medaan & 35,8 & 171 \\
\hline 5. & Modus & 37,8 & 81,6 \\
\hline 6. & Vanansi & 48,64 & 66,99 \\
\hline 7. & Sumpangan Baku & 6,974 & 8,184 \\
\hline
\end{tabular}

Dari tabel 4.1 data yang didapatkan setelah dilakukan uji pretest pada kelas eksperimen mendapati nilai tertinggi sebesar 50 sebanyak 1 peserta didik dan nilai terendah sebesar 21 . untuk lebih jelasnya data nilai dari uji pretest pada kelas eksperimen telah disusun disusun distribusi frekuensinya seperti terlihat pada tabel 3.2

TABEL 3.2 DISTRIBUSI FREKUENSI DATA PRETEST

\begin{tabular}{|c|c|c|c|c|c|}
\hline $\begin{array}{l}\text { Kelas } \\
\text { Intenval }\end{array}$ & $\begin{array}{l}\text { Thik } \\
\text { Butat } \\
\text { Buwah }\end{array}$ & $\begin{array}{l}\text { Titik Batas } \\
\text { Atas }\end{array}$ & $\begin{array}{l}\text { Feloothe } \\
\text { Absolat }\end{array}$ & $\begin{array}{l}\text { Krokons } \\
\text { Kumulatif }\end{array}$ & $\begin{array}{l}\text { Fokuena } \\
\text { Relatif(4) }\end{array}$ \\
\hline 2135 & 20,5 & 235 & 3 & 3 & 73 \\
\hline 26.50 & 25,3 & 30.5 & 10 & 13 & 25 \\
\hline 31.35 & 30,3 & 35,5 & 8 & 19 & 15 \\
\hline 36.40 & 35,5 & 40,5 & 13 & 32 & 32,5 \\
\hline 4145 & 40,5 & 45,5 & 5 & 37 & 13,51 \\
\hline 46.50 & 45,5 & 50,5 & 3 & 40 & 33 \\
\hline
\end{tabular}

Sehingga dari data diatas apabila dibuat menjadi gambar grafik histogram menjadi sebagai berikut : 


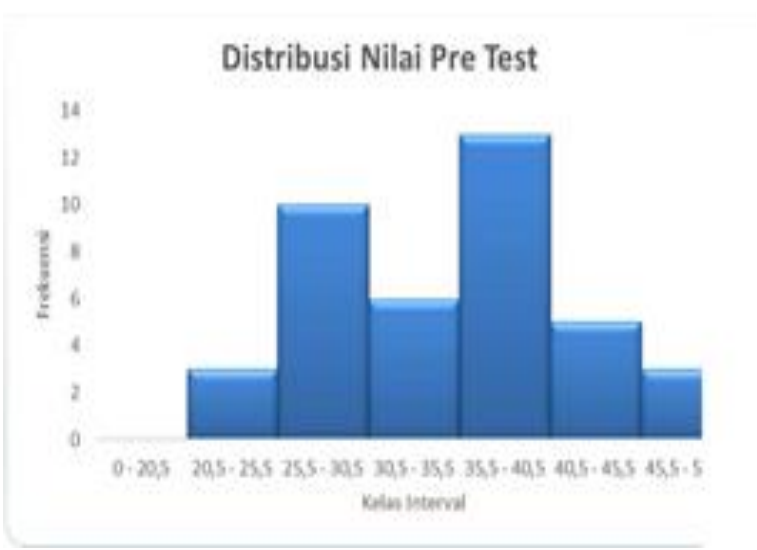

Gambar 3.1 Histogram Pretest Eksperimen

Seperti yang telah ditunjukkan pada tabel 4.1 bahwa terdapat nilai tertinggi yaitu sebesar 85 sebanyak 8 siswa dan nilai terendah yaitu sebesar 56 sebanyak 1 siswa. Data nilai peserta didik dari uji postest kelas eksperimen disusun distribusi frekuensinya seperti terlihat pada tabel 4.3

TABEL 3.3 DISTRIBUSI FREKUENSI DATA POSTTEST

\begin{tabular}{|c|c|c|c|c|c|}
\hline $\begin{array}{l}\text { Kelas } \\
\text { Interval }\end{array}$ & $\begin{array}{l}\text { Butal } \\
\text { Bamah }\end{array}$ & EatasNess & $\begin{array}{l}\text { Fitécueni } \\
\text { Abolke }\end{array}$ & $\begin{array}{l}\text { Fekunasi } \\
\text { Kumalatif }\end{array}$ & $\begin{array}{l}\text { Rethueni } \\
\text { Relutif(60) }\end{array}$ \\
\hline $56 \$ 0$ & 53.5 & 60.5 & $t$ & 1 & 0,025 \\
\hline 61.65 & 60,5 & 65,5 & 4 & 3 & 0,1 \\
\hline 66.0 & 653 & 70,5 & 5 & 10 & 12,5 \\
\hline 71253 & 70,5 & 73,5 & 3 & II & 20 \\
\hline 76.50 & 75,5 & 80,5 & 8 & 26 & 20 \\
\hline $81 \$ 5$ & 30,5 & 85,5 & 14 & 40 & 35 \\
\hline
\end{tabular}

Pada gambar 3.2 menunjukkan diagram dari distribusi frekuensi yang didapat dari data nilai posttest.

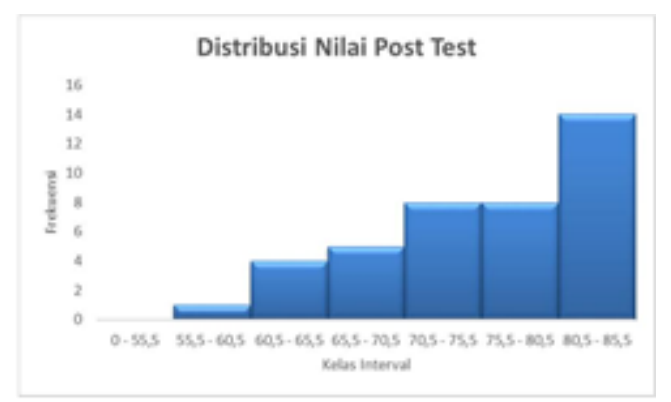

Gambar 3.2 Histogram Posttest Eksperimen

\subsection{Pengujian Persyaratan Analisis}


Dari hasil uji normalitas pada kelas penelitian menggunakan chi-kuadrat dengan taraf signifikansi 5\% maka didapatkanlah data seperti pada tabel 3.4 berikut :

\subsection{Pengujian Hipotesis}

TABEL 3.4 Uji Normalitas Data

Berikut adalah hasil perhitungan uji hipotesis menggunakan uji-t untuk dua sample related dan menggunakan uji pihak kanan yang disajikan pada tabel 3.5data seperti pada tabel berikut :

TABEL 3.5 Pengujian Hipotesis

\begin{tabular}{|c|c|c|c|c|c|}
\hline a & Data & Dik:1 & Sines & wet & Koumpulas \\
\hline 0.05 & Deperimean & $(40-1)=19$ & 35,60379252 & 1.954875122 & 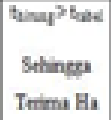 \\
\hline
\end{tabular}

Berdasarkan hasil data dari perhitungan menggunakan uji $t$ dan melihat pada tabel $t$ student dengan taraf signifikansi $0,05 \%$ pada pihak two tail test maka didapatkanlah hasil bahwa thitung sebesar 38,60379252 dan ttabel (tabel t-student) sebesar 1,684875122 maka dapat disimpulkan bahwa hasil dari thitung $>$ ttabel maka Ho ditolak yang berarti benar adanya terdapat pengaruh media pembelajaran berbasis E-Learning terhadap hasil belajar dibandingkan dengan hasil dari pretest sebelum diberikan perlakuan dan postest setelah diberikan perlakuan.

\section{Kesimpulan}

Peneliti menyimpulkan bahwa penggunaan media pembelajaran berbasis E-Learning Schoology terbukti berpengaruh positif dalam meningkatkan hasil belajar peserta didik. Selain itu pada kelas eksperimen didapatkan rata rata gain (peningkatan nilai) dari pretest dan postest kelas eksperimen sebesar 40 yaitu terdapat perbedaan antara nilai pretest dan posttest.

\section{DATAR PUSTAKA}

1. FT] Fakultas Teknik. (2015). Buku Panduan Penyusunan Skripsi dan Non Skripsi. Jakarta: Fakultas Teknik, Universitas Negeri Jakarta.

2. Arsyad, Azhar. (2011). Media Pembelajaran. Jakarta: PT RajaGrafinfo Persada.

3. Efendi, E. \& H, Zhuang., (2005), E-Learning Konsep dan Aplikasi. Yogyakarta: Penerbit ANDI,.

4. Eveline dan Hartini. (2010). Teori Belajar dan Pembelajaran. Bogor: Ghalia Indonesia.

5. Hamalik, Oemar. (2005). Proses Belajar Mengajar .Jakarta:Bumi Aksara.

6. Kustija, Jaja. (2012). Modul Sensor dan Transduser. Jakarta: Universitas Mercubuana.

7. Lulu Choirun Nisa.2012. Pengaruh Pembelajaran E-Learning Terhadap Hasil Belajar Mata Kuliah Statistics Mahasiswa Tadris Bahasa Inggris Fakultas Tarbiyah Iain 
Walisongo : studi kasus di Fakultas Tarbiyah IAIN Walisongo Semarang. Jurnal Phenomenon. 2:7.

8. Purwanto. (2009). Evaluasi Hasil Belajar .Yogyakarta : Pustaka Pelajar.

9. Rusmadi, Dedi. (2007). Belajar Rangkaian Elektronika Tanpa Guru. Bandung: Penerbit,DelFajar Utama.

10. Ridwan, Muhammad Najib. (2019). Pengaruh Implementasi Media Pembelajaran Berbasis E-Learning Schoology Pada Mata Pelajaran Dasar Listrik dan Elektronika di SMK Mitra Industri MM2100 Kelas X Jurusan Teknik Elektronika Industri. Jakarta:

11. Santoso, Djoko \& Setianto Heru. (2013). Teori Dasar Rangkaian Kelistrikan. Yogyakarta: Cv Aswada Presindo.

12. Sugiyono. (2013). Metode Penelitian Pendidikan (Pendekatan Kuantitatif, Kualitatif, Dan R\&D). Bandung: Alfabeta.

13. Wahyuningsih, Dian \& Makmur Rahmat. (2017). E-Learning Teori dan Aplikasi. Bandung: Informatika Bandung.

14. Widodo, Sapto (2014). Dasar dan Pengukuran Listrik Semester 1. Jakarta: Kementrian Pendidikan dan Kebudayaan Republik Indonesia.

15. Waluyanti, Sri., Santoso, Djoko., Slamet., Rochayati, Umi. (2008). Alat Ukur dan Teknik Pengukuran. Jakarta :Direktorat Pembinaan Sekolah Menengah Kejuruan, Direktorat Jendral Manajemen Pendidikan Dasardan Menengah, Departemen Pendidikan Nasional.Sutopo, A.H. (2003). Multimedia Interaktif dan Flash. Yogyakarta: PT Graha Ilmu

16. Yatim, R. (2009). Paradigma Baru Pembelajaran. Jakarta: Kencana 